\title{
MIKÄ ON OPETTAJAN IDENTITEETTI, KUN OPETUS MUUTTUU PROJEKTILUONTEISEKSI?
}

\section{JYRKIJOKINEN(2002) \\ Aikuisopettajan identiteetti. Yksinäisestä sankariopetta- jasta tiimiytyneeseen yrittä- jään?}

Akateeminen väitöskirja. Acta Universitatis Tamperensis 898. Tampere University Press.

Tärkeässä kirjassaan Vapaan sivistystyön visiot. Castrénilaista laatuviiniä uusissa tammitynnyreissä Timo Toiviainen nostaa tutkimuksen yhdeksi vapaan sivistystyön lähitulevaisuuden visioksi. Onkin pantava ilolla merkille, että kansalais- ja työväenopistojen rehtoreilta on riittänyt energiaa myös väitöskirjojen tekoon. Jyrki Jokinen on nyt vuorostaan jatkanut Juha Sihvosen ja Arto Leistevuon viitoittamalla tiellä. Tämä on ollut sitäkin tärkeämpää, koska varsinainen akateeminen tutkimus ei ole juuri ollut innostunut viime aikoina vapaasta sivistystyöstä.

Jokisen työ on erityisesti käytännön kannalta relevantti ja ajankohtainen, kuten vastaväittäjätkin lausunnossaan mainitsevat.(Aikuis)opettajakaan ei voi piiloutua yhteiskunnan muutoksilta, vaikka halukkuutta näyttäisi olevan yllättävänkin paljon. Tekijällä on erittäin hyvä koko aikuiskoulutuskentän sekä koulutuspolitiikan tuntemus, mutta kuitenkin se jää itse työssä irralliseksi osioksi hedelmöittämättä kunnolla varsinaista tutkimustehtävää. Jokisen peruskäsite on identiteetti, jonka hän jakaa vielä persoonalliseen, sosiaaliseen ja ammattiidentiteettiin. Identiteetti ei kä- sitteenä ole niitä helpoimpia onko yleensä helppoja tieteellisiä käsitteitä? Ja vaikka tekijä pyörittelee käsitettään yli 20 sivua, lopputulokseksi jää kuitenkin tietty hämmennys.

Pätevyyteni ei riitä arvioimaan tutkimusmenetelmäksi valittua elämäkertametodia, mutta jotenkin tekijän metodisista valinnoista jää epämääräinen kuva. Tekijä itse pitää tutkimustaan kvalitatiivisena, mutta kvantitatiivisuuttakin on mukana. Vanhana behavioralistina ja monimuuttujamenetelmien pyörittäjänä olen aina hieman vaikeuksissa arvioidessani kvalitatiivisia menetelmiä ja erityisesti näin saatujen tulosten yleistysarvoa ja todistusvoimaa. Niin nytkin. Onneksi Pertti Töttö pitää uljaasti kvantitatiivisten menetelmien puolta.

Miksi muuten puhutaan elämäkerrasta mutta elämänkertomuksista? Vielä yksi rakenteellinen huomautus Jokisen väitöskirjaan: on hieman outoa, että tutkimuskysymykset tulevat vastaan vasta sivulla 130 , noin puolivälissä koko teosta.

Mutta palataan identiteettiin ja Jokisen väitöskirjan tuloksiin. Varsin pienen aineistonsa - yhteensä 20 aikuiskoulutuskeskuksen, aikuislukion ja kansalaisopiston opettajaa - perusteella Jokinen saa tulokseksi seuraavat opettajatyypit: perusopettaja, suunnittelijaopettaja, nonstop-opettaja ja projektiopettaja. Olen itse opettanut noin 35 vuotta ja opetan edelleenkin, jopa pidän opettamisesta. Mutta en ole koskaan oikein pitänyt itseäni opettajana, pikemminkin tutkijana-johtajana. Eli onko mahdollista, että minulta puuttuu kokonaan opettaja-identiteetti? Toinen Jokisen väitöskirjan tuloksista nouseva kysymys kuuluu: Eikö ole aivan turhaa haikailla enää "puhtaan" opettaja-identiteetin perään tässä projektivetoisessa koulutusmaailmassa? Omassa opistossanikin, Tampereen työväenopistossa olemme yrittäneet kouluttaa jopa tuntiopettajiamme alihankkijoiksi, eli kun he hakevat meille töihin, väärin muotoiltu kysymys kuuluu: onko teillä saksan kielen opettajalle töitä, ja oikea kysymys taas vastaavasti: olen kehittänyt tällaisen saksan kielen opetukseen soveltuvan tuotteen, onko teillä sille käyttöä.

Kansalais- ja työväenopistojen liiton toiminnanjohtaja-ajalta minulle on jäänyt Jyrkistä sellainen mielikuva, ettei hän ole mikään verbaalivirtuoosi, mutta väitöskirjan teksti on ihan sujuvaa luettavaa. Ehkäpä kiitokset suomen kielen tarkastajalle ovat todella paikallaan. Itse väitöstilaisuudessa Jyrki puolusti tekemisiään erittäin ansiokkaasti, ja kun vielä vastaväittäjät Kyösti Kurtakko ja Risto Honkonen erittelivät teosta juohevasti, tuloksena oli tyylikäs akateeminen tilaisuus, jossa kuulijakin viihtyi.

\section{Pertti Timonen}

